Revista Universo Contábil, ISSN 1809-3337
Blumenau, v. 15, n. 2, p. 78-96, abr./jun., 2019
dot:10.4270/ruc.2019213

\title{
THE EFFECT OF DEBT CHARACTERISTICS ON THE RECOGNITION OF IMPAIRMENT LOSSES
}

\section{O EFEITO DE CARACTERÍSTICAS DO ENDIVIDAMENTO NO RECONHECIMENTO DE PERDAS NO VALOR RECUPERÁVEL DE ATIVOS}

\section{EFECTO DE LAS CARACTERÍSTICAS DE LA DEUDA SOBRE EL RECONOCIMIENTO DEL DETERIORO DEL VALOR DE LOS ACTIVOS}

Recebido em: 11/01/2019

Avaliado em: 21/08/2019

Reformulado em:20/10/2019

Aceito para publicação em: 28/10/2019

Publicado em: 30/11/2019

Editor Responsável: Moacir M. Rodrigues Junior

\author{
Davi Souza Simon 1 \\ Clea Beatriz Macagnan ${ }^{2}$
}

\begin{abstract}
This paper investigates the role played by debt regarding impairment practices of Brazilian publicly traded firms when there are market expectations for the booking of impairment losses, motivated by the premise that debt contracting is the most important source of demand for impairment rules. Our sample of Brazilian publicly traded firms includes 206 unique firms and 7 calendar years, resulting in 1010 firm-year observations. Within this setting, 98 out of 206 firms are in persistently low marketto-book states in at least one period during our sample years. Despite that, there are only 51 firm year observations, regarding only 21 unique firms, in which an impairment loss was recorded. We test debt related hypothesis analyzing the statistical relation between the level of unrecognized economic losses and four debt related variables, the debt to equity ratio, the ratio of short-term debt to total debt, the presence of bonds in the companies' liabilities and the level of debt financing in the year $t$. We report evidence that there is an inverted $u$-shaped relationship between leverage and the level of unrecognized losses. This result suggests that accounting conservatism decreases once the firm secures debt funding but increases for more indebted firms. Short term debt is positively associated to the level of unrecognized impairment losses, indicating that the constant monitoring managers are subject to when they have to frequently renegotiate debt substitutes for accounting conservatism.
\end{abstract}

Keywords: Impairment; Accounting Conservatism; Debt.

\section{RESUMO}

Este artigo investiga o papel desempenhado pela dívida em relação às práticas de redução ao valor recuperável de empresas de capital aberto brasileiras quando existem expectativas do mercado para o registro de perdas por impairment, motivadas pela premissa de que a contratação de dívida é a fonte

\footnotetext{
${ }^{1}$ Mestre em Ciências Contábeis pela Universidade do Vale do Rio dos Sinos (UNISINOS); Doutorando do Programa de Pós-Graduação em Ciências Contábeis da Universidade do Vale do Rio dos Sinos (UNISINOS); E-mail: davi.simon.cnh@gmail.com

${ }^{2}$ Doutora em Creación, Estrategia y Gestión de Empresas pela Universitat Autònoma de Barcelona (UAB); Professoras do Programa de Pós-Graduação em Ciências Contábeis da Universidade do Vale do Rio dos Sinos (UNISINOS). E-mail: cleabeatrizm@gmail.com
} 
mais importante de demanda por regras de redução ao valor recuperável. A amostra foi composta por empresas brasileiras de capital aberto inclui 206 firmas para 7 anos, resultando em 1010 observações ano-empresa. Dentro desse cenário, 98 de 206 empresas estão em estados persistentemente baixos de Market-to-Book, em pelo menos um período durante os anos da amostra. Apesar disso, existem apenas 51 observações (firma-ano), referentes a apenas 21 firmas, nas quais foi registrada uma perda por redução ao valor recuperável. Foi testada a hipótese relacionada à dívida, analisando a relação estatística entre o nível de perdas econômicas não reconhecidas e quatro variáveis relacionadas à dívida, a relação dívida pelo patrimônio líquido, razão entre dívida de curto prazo e dívida total, presença de títulos no passivo das empresas e nível de financiamento da dívida no ano t. Foi encontradas evidências de que existe uma relação na forma de $U$ invertido entre a alavancagem e o nível de perdas não reconhecidas. Esse resultado sugere que o conservadorismo contábil diminui quando a empresa obtém o financiamento da dívida, mas aumenta para as empresas mais endividadas. A dívida de curto prazo está positivamente associada ao nível de perdas por redução ao valor recuperável não reconhecidas, indicando que o monitoramento constante da gestão está sujeito a necessidade de renegociar com frequência substitutos da dívida para conservadorismo contábil.

Palavras-Chave: Impairment; Conservadorismo Contábil; Dívida.

\section{RESUMEN}

Este estudio investiga el papel desempeñado por la deuda en relación con las prácticas de reconocimiento de deterioro del valor de los activos de las empresas que cotizan en bolsa en Brasil cuando existen expectativas de mercado para reconocimiento de deterioro, motivado por la premisa de que la contratación de deuda es la fuente más importante de demanda de reglas de deterioro. Nuestra muestra de firmas brasileñas que cotizan en bolsa incluye 206 firmas únicas y 7 años calendario, lo que da como resultado 1010 observaciones por año y empresa. En este contexto, 98 de las 206 empresas se encuentran en estados en que el importe en libros de los activos netos de la entidad es mayor que su capitalización bursátil en al menos un período durante nuestros años de muestra. A pesar de eso, solo hay 51 observaciones, con respecto a solo 21 empresas únicas, en las cuales se registró una pérdida por deterioro. Probamos hipótesis relacionadas con la deuda analizando la relación estadística entre el nivel de pérdidas económicas no reconocidas y cuatro variables relacionadas con la deuda, la relación deuda / capital, la relación entre la deuda a corto plazo y la deuda total, la presencia de bonos en los pasivos de las empresas y el nivel de financiación de la deuda en el año t. Presentamos evidencia de que existe una relación en forma de U invertida entre el endeudamiento y el nivel de pérdidas no reconocidas. Este resultado sugiere que el conservadurismo contable disminuye una vez que la empresa asegura el financiamiento de la deuda, pero aumenta para las empresas más endeudadas. La deuda a corto plazo se asocia positivamente al nivel de pérdidas por deterioro no reconocidas, lo que indica que los gerentes de monitoreo constante están sujetos a cuando tienen que renegociar con frecuencia sustitutos de la deuda para el conservadurismo contable. Palabras clave: Deterioro; Conservadurismo Contable; Deuda.

\section{INTRODUCTION}

This paper investigates the influence of debt on the impairment practices of Brazilian publicly traded firms, particularly when there are market expectations for the booking of impairment losses. According to the rules set by IAS 36 - Impairment of Assets, adopted in Brazil since 2010, reporting entities must constantly monitor the recoverable value of their long-lived assets, assuring that no asset is reported in an entity's financial reports when its outstanding value is estimated to be unrecoverable through sale or usage. Impairment rules are an important mechanism of conditional accounting conservatism within the International Financial Reporting Standards (IFRS) (André, Filip, \& Paugam, 2015). Conditional conservatism should reduce the level of information asymmetry between 
firms and market capital providers, through higher quality accounting information (Florou, \&Kosi, 2015; Leuz, \& Wysocki, 2016).

However, the extant literature on impairment rules show that impairment losses are frequently delayed or avoided, reducing the level of conditional conservatism with potentially negative effects on capital markets (Bini, \& Penman, 2013; European Security Markets Authority, 2013; André, Filip, \& Paugam, 2015; Bond, Govendir, \& Wells, 2016; Healy, 2016). While firms are required to disclose information on impairment tests, early evidence after the adoption of IFRS in 2010 shows that Brazilian firms fail to disclose complete information on impairment tests (Uliano, Doná, \& Gonçalves, 2014; Mazzioni et al. 2014).

The extant literature considers debt contracting is the most important source of demand conditional conservatism (Ball, Robin, \& Sadka, 2008; Göx, \& Wagenhofer, 2009). Under the standard principal-agent paradigm from agency theory, conditional conservatism can mitigate agency conflicts and facilitate efficient debt contracting (Armstrong, Taylor, \& Verrecchia, 2016). In order to analyze the relation between debt and impairment practices, we start by relying on the theoretical model of optimal impairment rules, constructed by Göx and Wagenhofer (2009.

Göx and Wagenhofer (2009) present an analytical solution evidencing that the ex-ante adoption of an accounting system that recognizes impairment losses in an optimal accounting policy for firms that will approach lenders in search of debt financing, and do not have an excess of pledgeable assets. Göx and Wagenhofer (2009) show that when an accounting system is designed to reports only high asset values, the firm would not obtain financing when reports the original book value of its pleadgeable assets, because a rational lender would take the unadjusted book value as bad news. Contrarily, when the firm is committed ex ante to report only lower values of its assets, the lender will rationally interpret unadjusted book values as good news. Consequently, book value of an impaired asset provides more precise information about the asset value than the book value of an unimpaired asset, as the book value of the impaired asset carries only the uncertainty about the asset value resulting from the measurement process, whereas the unimpaired book value has a larger uncertainty depending on the size of the set of values for which there is nondisclosure.

Based on Göx and Wagenhofer (2009), we expect that firms would book impairments according to market expectation when they seek funding through debt. Hence, missing impairments in the Brazilian context could be related to the peculiar way Brazilian firms utilize debt as a source for financing their projects, as the Brazilian debt market is largely dominated by bank credit and with underdeveloped public market for debt, with a high frequency of firms under financial constraints (Zani, \& Procianoy, 2007). Since private lenders (banks) are more likely to have access to private information, to engage in producing information, to monitoring borrowers, and renegotiating debt following initial issuance, relying less on financial statements than the level of reliance expected for public lenders (Florou, \& Kosi, 2015), Brazilian firms could be delaying or avoiding impairment recognition when their debt is obtained from banks.

Göx and Wagenhofer (2009) model a firm that needs external financing, but do not analyze the behavior of the firm after securing funding. Due to agency problems, firms could prefer delaying or avoiding impairment recognition once there are covenants in place that could be affected by impairment losses. This preference is counteracted by the banks' and other creditors' desire to oversight the value of collateral, which increases on the likelihood of default. Hence, unrecognized impairment losses should increase once the firm has secured sufficient financing for its projects, until the risk of default reaches a critical value, in which there is incentive for banks and creditors to demand for impairment of assets pledged as collateral. Thus, an increased reliance on balance sheet information by lenders is expected when leverage levels are high. When debt becomes a more significant source of financing for the firms, the level of unrecognized losses should decrease, resulting in a non-linear relation between debt and unrecognized losses.

Our sample of Brazilian publicly traded firms includes 206 unique firms and 7 calendar years, resulting in 1010 firm-year observations. Within this setting, 98 out of 206 firms are in persistently 
high book-to-market states in at least one period during our sample years. Despite that, there are only 51 firm year observations, regarding only 21 unique firms, in which an impairment loss was recorded. In contrast to the report from Oler (2015), according to whom $19 \%$ of the firm-quarter observations between 1990 and 2010 presented high BTMs, our sample from Brazilian firms from 2010 to 2016 has around $30 \%$ of firm-years with two-year BTM > 1, a figure more similar to that reported by Bini and Penman (2013) regarding European companies.

There is clearly a low frequency of impairment recognition and disclosure practiced by Brazilian publicly traded companies. Although market participants cannot directly observe estimates made by firms on the recoverable value of their assets, the market value of firms could provide an indirect aggregate estimate of their net assets' recoverable amount. In this sense, this study considers a persistently high book-to-market ratio (BTM) as a potential impairment indicator, inspired by Ramanna and Watts' (2012) assertion that the market expects impairment losses on firms with bookto-market ratios higher than one $(\mathrm{BTM}>1)$ for a period of at least two consecutive years.

Within the Brazilian context of firms with concentrated ownership (Schiehll, Terra, \& Victor, 2013), agency motivations for accounting conservatism lead to the expectation of a high frequency of impairment losses, as controlling shareholders typically would prefer to retain earnings (Decourt, \& Procianoy, 2012). Earnings retention is facilitated by booking an impairment loss. Since the low frequency of recognized impairment losses by Brazilian firms suggest the contrary of agency-based expectations, our first hypothesis focus on the relation between debt and the actual recognition of impairment losses, while controlling for agency reasons and economic indicators of impairment $(\mathrm{BTM}>1)$.

Our results show that a persistent BTM $>1$ in the Brazilian context is not clearly associated with the recognition of impairment losses. While some of our tests show that a persistent BTM $>1$ is a statistically significant predictor of the booking of impairment losses, this effect results in little practical significance, as in our sample, impairment recognitions are much rarer than high BTM. This finding should be of interest to regulators and policy makers in the Brazilian context and in international markets, as it highlights that impairment rules are not achieving their objective of faithful representation.

Given the scarcity of booked impairment losses in our sample, even in scenarios in which firms have a persistently high BTM ratio, we turn our attention to the level of firms' unrecognized impairment losses. It is important to emphasize that BTMs smaller than 1 are expected for firms with solid financial position and growth opportunities, as the firms' market prices should capture positive expectations about future cash inflows earlier than these expectations are captured by accounting numbers (book value). However, when BTMs are larger than 1, and particularly for extended periods of time, there is a market expectation that the firm's assets are overvalued and that an impairment loss should be booked according to IAS 36. Consequently, market and book values should become correlated after the BTM stays larger than one for an extended period of time.

Given the expectation that the market value of a firm's net assets is uncorrelated with the book value of the same assets when the firm's BTM is smaller than 1, and it becomes correlated otherwise, we estimate the level of unrecognized impairment losses by one minus the inverse of the firm's BTM ratio, whenever this ratio is greater than 1 for year $\mathrm{t}$ and $\mathrm{t}-1$, and zero otherwise. With this measure, we estimate the percentage of firms' equity book value that is not supported by the firms' market value, characterizing an extreme situation in which market expects that the firm's future cash flows are not sufficient to recover the firm's net assets.

We test debt-related hypothesis analyzing the statistical relation between the level of unrecognized impairment losses and four variables, the debt to equity ratio, the ratio of short-term debt to total debt, the presence of bonds in the companies' liabilities and the net level of debt financing obtained in the year $t$. Our results show that there is a negative relation between the debt-to-equity ratio and the level of unrecognized losses, suggesting that contracting reasons create demand for conditionally conservative accounting. Short term debt is positively associated to the level of 
unrecognized impairment losses, indicating that the constant monitoring managers are subject to when they have to frequently renegotiate debt substitutes for accounting conservatism. Exploring the possibility of a non-linear relation between debt and the level of unrecognized impairment losses, we report evidence that there is an inverted u-shaped relationship between leverage and the level of unrecognized losses. This result can indicate that the demand for conservatism is larger for more indebted firms.

To the best of our knowledge, our study is the first to analyze firms expected unrecognized impairment losses. We also contribute to the accounting literature by showing an application of a Fractional Response Model in an accounting setting, as recommended by the recent econometrics' literature (Papke, \& Wooldridge, 2008; Gallani, \& Krishnan, \& Wooldridge, 2010). That happens because we measure unrecognized impairment losses as a fraction of the firms' net asset values that are not supported by firms' market capitalization, thus leading us to a fractional response data generating process, in which our dependent variable is constructed to be bounded at 0 and 1 .

We also contribute to the accounting literature by empirically exploring the possibility of a non-linear relation between debt and the level of unrecognized impairment losses, while confirming the theoretical expectation that short-term debt is a substitute for accounting conservatism, and that firms with larger debt-related financing cash flows have lower levels of unrecognized losses. Our findings highlight the multiple roles that can be played by debt when it comes to understanding the demand for accounting conservatism, which can lead to the development of improved and more generalizable analytical models of accounting conservatism and impairment rules. Our results also suggest that regulators and enforcers should direct more effort into monitoring firms' compliance with accounting rules, since we show that firms are not responding as expected by IAS 36 to economic indicators of impairment, and their response can be affected by the source of their funding. Finally, auditors can benefit from our findings by considering the nature of the firms' debt while assessing risks and planning their work on the auditing of impairment related estimates.

The remainder of this paper is organized as follows. In section 2, we present the hypotheses development. In section 3, sample data and research design are detailed. Results are presented in section 4 , followed by our concluding remarks in section 5 .

\section{HYPOTHESES DEVELOPMENT}

The timely recognition of asset write-offs, which are expected to be anticipated by markets, can be considered a form of conditional conservatism. In this sense, motivated by anecdotal evidence showing that managers have plenty of discretion to manage the timing of write-offs to take action related to earnings management, Choi (2008) investigates and obtains results suggesting that writeoffs are recorded in a less timely manner than other components of earnings. Hence, market prices over the years preceding a write-off take into account any decline in asset value reflected later in the write-off amount.

Ji (2013) presents evidence from the Australian context. Through examining the timing of goodwill impairment decisions of Australian companies during the period 2007 to 2009, the author reports that a non-trivial number of firms did not impair goodwill as called for under the standard governing asset impairment. Therefore, identifying potential economic losses prior to its recognition in a firm's financial statements can allow us to investigate the determinants of unrecognized losses.

The extant literature recognizes the complexity of identifying an economic loss at the firm level, given that impairment losses must be estimated at the cash generating unity level, and firms report at most at the business segment level (Guthrie; Pang, 2013; Detzen; Wersborg; Zulch, 2016; Knauer; Wöhrmann, 2016). The difficulty of this task is amplified by the limited disclosure practiced by firms regarding their impairment practices (Amiraslani, Iatridis, \& Pope, 2013; Glaum et al., 2013; Mazzi et al., 2017). 
A frequent empirical strategy adopted by the literature for identifying economic losses is to consider indicators of impairment derived from stock prices. Since Ball and Brown (1968), positive capital markets research utilizes the market prices and returns as a tool for measuring the utility of accounting information to market participants (Kothari, 2001). Kothari (2001) claims that an association between financial performance and market prices is expected in efficient markets. Based on the premise that market prices aggregate investor's opinions on the company's future cash flows, we argue that a persistent book value higher than the firm's market capitalization presents a situation in which market prices can proxy for an estimate of fair value of the company's net assets. This logic is similar to that presented by Danielson and Press (2003) and by Oler (2015), as both papers consider a book-to-market higher than one as a signal of lack of conservatism. Under accounting conservatism, impairment tests should follow persistently high BTM, correcting net asset's reporting value to reflect negative information already assimilated by the markets.

Ramanna and Watts (2012) take a large BTM ratio as an indicator of economic impairment, expected by the markets to be recognized in financial reports. When the BTM $>1$ for a period of at least two years, the authors state that it is reasonable to expect that the market aggregate opinion is that its assets are not fully recoverable. Even though Ramanna and Watts (2012) studies US publicly traded firms, its principle is also applicable to IFRS. Paugam, Astolfi, and Ramond (2015) emphasize that both US GAAP (SFAS 141R, SFAS 142, SFAS 144) and IFRS (IFRS 3, IAS 36) allow a significant space for managerial discretion, while Knauer and Wöhrmann (2016) report that markets react similarly to impairment losses within US-GAAP and IFRS.

This BTM-based identification strategy for expected impairment losses is followed by papers such as Mazzi et al. (2017). The BTM ratio is also listed by IAS 36 as an example of external indicators of impairment, along with technological and market change, which must be considered by management in their monitoring of impairment likelihood. These factors are out of the direct control of firms' management. They can indicate lower future cash flows or higher discount rates (Knauer, \& Wöhrmann, 2016). Riedl (2004) emphasizes that positive differences between market and book values create buffer that can absorb losses in some of the firm's cash generating unities. A BTM > 1 indicates that the firm's buffer has already been exhausted, and the firm is, therefore, in a situation of a very likely economic impairment.

In a report issued by KPMG's Global Valuation Institute, Bini and Penman (2013), analyzed a sample of firms in the US and European markets in 2008, 2009 and 2010, reporting a large prevalence of high BTM observations. This prevalence is larger in Europe (with a maximum frequency of 30,9\% in 2008) than in the US (20,2\% in 2008). Bini and Penman (2013) take this high BTM prevalence as a signal that there are widespread compliance problems regarding impairment rules.

Jarva (2014) argues that the high BTM identification strategy is reasonable given that analysts face more difficulties in forecasting future firm performance when BTM is high. Oler (2015) considers that firms with persistently high book-to-market ratios present an anomaly, probably due to aggressive accounting practices. Based on the above discussion, the extant literature relates high BTM ratios with an increased expectation of impairment losses recognition, resulting on the first hypothesis tested in the present study, which is presented as follows (in alternative form):

H1. Firms that have BTM higher than one should be more likely to recognize an impairment loss than firms with BTM lower than one, ceteris paribus.

Given the low frequency of booked impairment losses by Brazilian companies, we turn our focus to potential explanations regarding the level of firms unrecognized losses, that are taken as inconsistent with conditional conservatism. In order to explore the determinants of the level of unrecognized losses, our analysis considers the extant literature on the determinants of conditional accounting conservatism. 
The existence of accounting conservatism is explained by the extant literature mostly on contracting considerations, taxes, shareholder litigation risk, political process and regulatory forces (Basu, 1997; Watts, 2003b; Lu, \& Trabelsi, 2013). The evidence reported by Watts (2003a) suggests the contracting and shareholder litigation explanations are the most relevant, although effects of taxation and regulation play a smaller role. This expectation is confirmed by Ball, Robin, and Sadka's (2008) findings. Analyzing a sample of 78,949 firm-year observations during 1992-2003, with firms from 22 countries, the authors report evidence supporting their prediction that the level of conditional conservatism is predominantly shaped by debt markets.

The effect of debt contracting on accounting conservatism, and consequently on firm's propensity to recognize impairment losses, can be a result of the firm's demand for debt financing. Prior to obtaining debt financing, conservative impairment practices are the optimal policy in order to reduce market uncertainty about firm's collateral, improving the likelihood of raising debt capital (Göx, \& Wagenhofer, 2009).

After funding is obtained, agency problems can lead the firm to the opposite behavior regarding the recognition of impairment losses, given shareholders and managers objective of fulfilling covenants at the debtholders expense. Thus, a possible explanation for persistently high BTM could be managers' resistance to reduce asset values and consequently reduce their collateral (Chalmers, \& Godfrey, 2006; Filip, Jeanjean, \& Paugam, 2015). Gigler et al. (2009) go even further, showing analytically that the systematical recognition of impairment losses can be undesired from a social efficiency perspective, as it increases the cost of false alarms and results in the loss of informative power of conservative accounting.

This ambiguous effect of debt on the propensity of recognizing impairment losses leads us to expect the relation between debt and impairment losses to be non-linear. When the firm is still active in searching for funding, it should eliminate doubts about the value of its assets by recognizing any impairment loss that could have occurred. Unrecognized impairment losses should increase once the firm has secured sufficient financing for its projects, As leverage increases, the risk of default approaches a critical value, in which there is incentive for banks and creditors to demand for the recognition of collateral impairment if the economic circumstances suggest that the firm's assets have been impaired. Thus, we expect an increased reliance on balance sheet information by lenders when leverage levels are high. All of these debt related scenarios can result in a non-linear relation between debt and unrecognized losses, stated in hypothesis $\mathrm{H} 2$.

$\mathrm{H} 2 \mathrm{a}$. There is a non-linear association between debt and unrecognized impairment losses, ceteris paribus.

$\mathrm{H} 2 \mathrm{~b}$. The net level of funds obtained through debt financing in the year is negatively related to unrecognized impairment losses, ceteris paribus.

The use of collateral on financing arrangements is particularly important in the Brazilian market, where firms' access to debt financing is difficult. Zani and Procianoy (2007) reported that Brazilian publicly traded firms depend on collateral for debt financing regardless of their level of financial constrainedness, possibly as a function of the significant dependency on bank loans and the high volatility of the local economy. In this context, Private lenders (banks) are more likely to have access to private information, to engage in producing information, to monitoring borrowers, and renegotiating debt following initial issuance, relying less on financial statements than public lenders (Florou, \& Kosi, 2015). The prevalence of bank lenders then results in a lower demand for conservative accounting than the one expected on a market with a significant level of publicly traded debt.

The presence of short-term debt also substitutes for accounting conservatism as a strategy for mitigating agency costs, according to evidence presented by Khurana and Wang (2015). This substitution happens because short-term debt subject managers to more frequent monitoring due to 
debt renewals and renegotiations. The authors present evidence confirming the hypothesis that firms with greater levels of short-term debt present less conservative accounting practices. Missing impairments could be a result of how Brazilian firms utilize short term debt as a source of capital for financing their projects.

Considering the differential effects that market-traded and sort-term debt can have on the demand for conditional accounting conservatism, we formulate the following hypotheses, presented in alternative form:

H3a. Market-traded debt is negatively related to unrecognized impairment losses, ceteris paribus. $\mathrm{H} 3 \mathrm{~b}$. Short-term debt is positively related to unrecognized impairment losses, ceteris paribus.

\section{SAMPLE DESCRIPTION AND RESEARCH DESIGN}

To test our hypotheses, we use a sample of firm-years with complete data available between 2010 (the first year of full IFRS adoption in Brazil) and 2016, We require financial data from Standardized Financial Statements available at CVM (Brazilian Securities and Exchange Commission) and at the Economática database. We exclude firms in the financial services industries because of their different operating, financial and wealth generating structures. We also exclude companies with negative shareholders' equity on the previous year (for which market-to-book ratios are negative), companies with return on assets below $-100 \%$ and above $100 \%$, and companies with assets lower than one hundred thousand Brazilian Real. With this exclusion criteria, we exclude both firms that are likely to be in near-bankruptcy state and firms that experienced significant changes on their return on assets' generating processes. Finally, we excluded firms with negative debt-to-equity ratios, since the debt-to-equity ratio of these companies is not comparable to the other firms in the sample. As a result, our final sample is comprised by 1010 firm-year observations, with 206 unique Brazilian firms with stocks traded at the São Paulo Stock Exchange (currently denominated B3, formerly BM\&FBOVESPA).

Our first hypothesis, H1, considers that the existence of a persistently high BTM ratio should result in an increased likelihood of a firm recognizing an impairment loss. Hence, we test our hypothesis through a dummy variables approach. In our first specification, the dummy variable of interest takes the value 1 when the company has a BTM>1 for years $t$ and $t-1$, and zero otherwise, following Ramanna and Watts (2012). We also include in our first model debt related variables, allowing us to test hypotheses $\mathrm{H} 2$ and $\mathrm{H} 3$. Our first model is defined in the form or Eq.1. We present the definition of our variables of interest in Table 1. This model is estimated through a set of unbalanced Random Effects Logit models.

$$
\begin{aligned}
\text { D_Impairment }_{i, t} & \\
& =\beta_{0}+\beta_{1}\left(\text { Persistent Impairment Indicator }_{i, t}\right) \\
& +\beta_{2}\left(\text { Debt_to_equity }_{i, t-1}\right)+\beta_{3}\left(\text { Debt_to_equity }_{i, t-1}{ }^{2}\right)+\beta_{4}\left(\text { Short term debt }_{i, t}\right) \\
& +\beta_{5}\left(D_{-} \text {Bonds }_{i, t}\right)+\beta_{6}\left(\text { Financing Cash Flows }_{i, t}\right)+\sum_{k=1}^{22}\left\{\gamma_{k} \text { Control }_{k, i, t}\right\}+v_{i, t}
\end{aligned}
$$

\begin{tabular}{|c|c|}
\hline Variable & Definition \\
\hline \multicolumn{2}{|l|}{ Dependent Variable } \\
\hline D_Impairment $t_{i, t}$ & $\begin{array}{l}\text { dummy variable equals to } 1 \text { if the firm } i \text { recognized an impairment loss in year } \\
t \text { and zero otherwise. }\end{array}$ \\
\hline \multicolumn{2}{|l|}{ Independent Variables } \\
\hline Persistent Impairment Indicator ${ }_{i, t}$ & dummy variable that equals 1 if average BTM of the year $t$ and $t-1>1$; \\
\hline Debt to Equityi,t-1 & Debt-to-equity ratio in year $t-1$, winsorized at the $95 \%$ percentile $* 100$ \\
\hline
\end{tabular}

(Eq. 1)

Table 1 - Definition of variables of interest 


\begin{tabular}{|l|l|}
\hline Short term debt $\mathrm{i}_{\mathrm{i}, \mathrm{t}}$ & Short term debt divided by total debt; \\
\hline D_Bonds & $\begin{array}{l}\text { dummy variable equals to } 1 \text { if the firm } i \text { has bonds in its liabilities in year } t \\
\text { and zero otherwise. }\end{array}$ \\
\hline Financing Cash Flows \\
\hline i,t & $\begin{array}{l}\text { Cash flows from financing activities, measured as the net amount between } \\
\text { cash inflows obtained from debt financing and the cash outflow to repay debt } \\
\text { and interest, of firm } i \text { in year } t \text {, scaled by assets in year t-1 }\end{array}$ \\
\hline Controls $_{\mathrm{k}, \mathrm{t}}$ & Control Variables defined in Table 3 \\
\hline
\end{tabular}

We analyze the Brazilian context regarding the recognition of impairment losses first through Random effects logit regressions taking as dependent variable a binary indicator of impairment recognition, represented by variable $D \_i m p a i r m e n t$. Our Logit regression was estimated with panel data characteristics, following Wooldridge (2010).

Given the low frequency of actual recognitions of impairment losses, our second strategy is to focus our analysis on the potential unrecognized impairment loss. This strategy takes as dependent variable the unrecognized economic loss, measured by 1 minus the inverse of the BTM ratio at year $t$ whenever the firm has a BTM $>1$ for years $t$ and $t-1$, and zero otherwise, as defined in Table 2 . The two-year period adopted for identification in our tests follows the assertion by Ramanna and Watts (2012) that the market expects losses when there is persistence in the high BTM. The adoption of 1 minus the inverse of the BTM ratio results in unrecognized losses being measured as a percentage of the company's net assets. This leads us to equation 2.

Unrecognized Loss $_{i, t}$

$$
\begin{aligned}
& \left.=\beta_{0}+\beta_{1}\left(\text { Debt_to_equity }_{i, t-1}\right)+\beta_{2} \text { (Debt_to_equity }_{i, t-1}^{2}\right)+\beta_{3}\left(\text { Short term debt }_{i, t}\right) \\
& +\beta_{4}\left(D_{-} \text {Bonds }_{i, t}\right)+\beta_{5}\left(\text { Financing Cash Flows }_{i, t}\right)+\sum_{k=1}^{22}\left\{\gamma_{k} \text { Control }_{k, i, t}\right\}+v_{i, t}
\end{aligned}
$$

Table 2 - Definition of variables of interest

\begin{tabular}{ll}
\hline Variable & Definition \\
\hline Unrecognized Loss $\mathrm{i}_{\mathrm{i}, \mathrm{t}}($ Dependent $)$ & $1-[1 /$ ( BTM ratio) $]$ in year t when the company's BTM is greater than one \\
& in year t and $\mathrm{t}-1$, and 0 otherwise, winsorized at the 95\% percentile).
\end{tabular}

Note: Independent variables are the same that were defined in Table 1. Control Variables are presented in Table 3.

Contrary to Riedl's (2004) study, which uses Tobit regressions given the large number of observation with zero impairment losses, we take advantage of recent advances on the econometrics literature (Papke, \& Wooldridge, 2008; Gallani, Krishnan, \& Wooldridge, 2010) in which Tobit models are shown to be inappropriate for data in which there is no censoring, but only boundedness, which is the case of impairment losses. Given that Eq.2's dependent variable represents a fraction of a firm's total assets, we estimate the parameters of the model in Eq.2 through Generalized Estimating Equations approach (GEE). This kind of model is defined by Papke and Wooldridge (2008) as a Fractional Response Model, adequate for dealing with the possible shortcomings of Tobit models for fractional data. Differently from the Logit Model, which takes only a binary variable as dependent variable, the GEE approach allows for a dependent variable which takes variables from 0 to 1 , being suitable for proportions and percentages (Liang, \& Zeger, 1986).

The parameters of the model described in Eq. (2) are estimated with the full sample of 1010 firm-years. We follow this procedure since we are interested in the reasons some companies do not recognized impairment losses, while others do recognize such losses, controlling for the effect of several variables that are indicative of economic losses, considered in our control variables as defined in Table 3. Through this estimation, we avoid the problem of Conditional-on-positive effects, in which the model effects do not have causal interpretation, due to the kind of selection bias that motivated the development of censored regression models (Angrist, \& Pischke, 2008). As Angrist and Pischke (2008) reason, in search of causal effects, $y_{i}>0$ is an equation outcome, which cannot therefore be conditioned on, unless the matrix $\mathrm{X}$ of covariates have no effect on the likelyhood of y $i$ being positive. 
Regarding our model's control variables, defined in Table 3, Banker, Basu, and Byzalov (2014) argue and report empirical confirmation to the notion that earnings exhibits asymmetric timeliness with respect to multiple signals, including stock return, sales change, and operating cash flow change. Banker, Basu, and Byzalov (2017), based in Basu's (1997) asymmetric timeliness model, modified the original model through the inclusion of changes in sales and operating cash flows, and the substitution of the dependent variable, earnings scaled by the beginning of year market value of the entity, by asset write-downs. The authors predicted and confirmed empirically a complex chain of interactions between indicators of changes in sales and operating cash flows. We take the variables in Banker, Basu, and Byzalov's (2017), including those from Riedl (2004), which are practicable to our analysis of Brazilian data, as control variables in order to build our model. It is worthy to emphasize that, despite the criticism to which the Basu's (1997) model has been subject to, Ball, Kothari, and Nikolaev (2013a) confirm its validity of an econometric strategy of identification of conditional conservatism when it is actually present.

As in Banker, Basu, and Byzalov's (2017), we also consider interactions between control variables $\Delta \mathrm{CF}_{\mathrm{i}, \mathrm{t}}$ and $\mathrm{DC}_{\mathrm{i}, \mathrm{t}}, \Delta \mathrm{SALES}_{\mathrm{i}, \mathrm{t}}$ and $\mathrm{DS}_{\mathrm{i}, \mathrm{t}}$, and $\Delta \mathrm{E}_{\mathrm{i}, \mathrm{t}}$ and $\mathrm{DE}_{\mathrm{i}, \mathrm{t}}$. These interactions should capture the asymmetric timeliness of bad news, measured as negative variation on cash flows, sales and preimpairment earnings. Results reported by Wrubel, Marassi, and Klann (2015) regarding the Brazilian market show that changes in cash flow, revenue and debt, and income smoothing practices do determine the recognition of impairment losses.

Table 3 - Definition of Control Variables

\begin{tabular}{|c|c|}
\hline Variable & Definition \\
\hline$R E T_{i, t}$ & stock return for the 12-month period of fiscal year $t$ \\
\hline$D R_{i, t}$ & dummy variable that equals 1 if stock return $R E T t$ is negative. zero otherwise; \\
\hline$\Delta C F_{i, t}$ & $\begin{array}{l}\text { change in operating cash flow from year } t-1 \text { to year } t \text {, scaled by total assets at the beginning } \\
\text { of the year; }\end{array}$ \\
\hline$D C_{i, t}$ & dummy variable that equals 1 if cash flow change $\Delta C F t$ is negative, zero otherwise; \\
\hline$\triangle S A L E S_{i, t}$ & change in sales from year $t-1$ to year $t$, scaled by total assets at the beginning of the year; \\
\hline$D S_{i, t}$ & dummy variable that equals 1 if sales change $\triangle S A L E S t$ is negative, zero otherwise; \\
\hline$\Delta E_{i, t}$ & change in pre-writedown earnings in year $t$, scaled by total assets at the beginning of the year; \\
\hline$D E_{i, t}$ & dummy variable that equals 1 if $\Delta E_{t}<0$, zerootherwise; \\
\hline$\Delta G D P_{t}$ & GDP growth in year $\mathrm{t}$; \\
\hline$\triangle I N D R O A_{i, t}$ & change in median industry ROA for the industry of the firm in year $t$; \\
\hline$B A T H_{i, t}$ & $\Delta E_{t}$ if $\Delta E_{t}$ is below the median of the negative tail of $\Delta E_{t}$, zero otherwise; \\
\hline $\mathrm{SMOOTH}_{i, t}$ & $\Delta E_{t}$ if $\Delta E_{t}$ is above the median of the positive tail of $\Delta E t$, zero otherwise; \\
\hline Liquidity $_{i, t}$ & Liquidity of the stock $i$ in year $t$, as defined in Equation 3. \\
\hline $\log \left(\right.$ assets $\left._{\mathrm{i}, \mathrm{t}}\right)$ & Log of total assets of firm in year $_{\mathrm{t}-1)}$ \\
\hline D_StockOptions & $\begin{array}{l}\text { dummy variable equals to } 1 \text { if firm } i \text { has informed stock options granted to managers in year } \\
t \text { and zero otherwise. }\end{array}$ \\
\hline D_VariableComp & $\begin{array}{l}\text { dummy variable equals to } 1 \text { if firm } i \text { has informed variable compensation paid to managers in } \\
\text { year } t \text { and zero otherwise. }\end{array}$ \\
\hline Goodwill $_{i, t}$ & Goodwill of firm ${ }_{\mathrm{i}}$ in year $t$ scaled by total assets \\
\hline Volatility ${ }_{\mathrm{i}, \mathrm{t}}$ & $\begin{array}{l}\text { Volatility of quarterly earnings in the past three years of firm }{ }_{i} \text { in year } t \text { scaled by earnings in } \\
\text { year } t\end{array}$ \\
\hline Growth Opportunitiesi,t & Investment Cash Flows scaled by Fixed and Intangible assets of firm $i$ in year $t$ \\
\hline Fixed Assets $s_{i, t}$ & Fixed assets scaled by total assets of firm $i$ on period $t$ \\
\hline Intangibles $\mathrm{i}_{\mathrm{i}, \mathrm{t}}$ & Intangible Assets, except goodwill, scaled by total assets of firm $i$ on period $t$ \\
\hline Payout & Dividends paid in year $t$ divided by net income in year $t-1$ \\
\hline Ownership $_{\mathrm{i}, \mathrm{t}}$ & (\%) voting shares held by the largest shareholder of firm $i$ in year $t$ \\
\hline
\end{tabular}

Given that the Brazilian stock market is significantly smaller than the American stock market, and that there is significant variance on the Brazilian Companies market capitalization, we also included stock liquidity as a control variable. This inclusion was operationalized through the exchange liquidity index, provided by the Economática database, and calculated as follows: 


$$
\text { Liquidity }=100 * \frac{p}{P} * \sqrt{\left(\frac{n}{N} * \frac{v}{V}\right)}
$$

where:

$\mathrm{p}=$ number of days on which there was at least one trade with the share within the chosen period

$\mathrm{P}=$ total number of days in the chosen period

$\mathrm{n}=$ number of trades with the share within the chosen period

$\mathrm{N}=$ number of trades with all shares within the chosen period

$\mathrm{v}=$ volume in cash regarding the share within the chosen period

$\mathrm{V}=$ cash volume regarding all shares within the chosen period

Growth opportunities, suggested by Göx and Wagenhofer (2009) as a potential predictor of impairment losses, are usually proxied by stock price-based ratios, such as Tobin's Q (Kogan, \& Papanikolaou, 2014). However, in the case under analysis, the presence of unrecognized economic losses means that measures of investment opportunities based on the relation between stock prices and value of assets suffer due to the problem of questionable asset measurement. Alternatively, we take the investment cash flow (CAPEX) divided by fixed and intangible assets as a proxy for growth (Kallapur, \& Trombley, 1999; Adam, \& Goyal, 2008).

We also consider the payout level and ownership concentration as control variables. Szczesny and Valentincic (2013) analyzed private firms and reported evidence that such firms make the decision to write off, and write off more in terms of total amount, when they are: (i) more profitable, (ii) have more financial debt, and (iii) pay dividends. In their opinion, asset write-offs are viewed as corrections of departures of book values from their underlying economic values, resulting on a potential adjustment on the stream of dividends to shareholders. Even though their study is based on private firms, we understand that firms that pay more dividends would be economically better by reporting asset write-offs, reducing current levels of dividends and smoothing future dividends (due to effects such as reduced depreciation expense).

\section{RESULTS}

Summary statistics of numeric variables are presented in Table 5. No pair of variables has correlation coefficient greater than 0.6 , which could suggest multicollinearity problems. Since we have 7 years of data for 82 of our sample firms, with an average of about 5 years per firm, the characteristics of our dataset lead us to an unbalanced panel dataset. With this dataset, we estimate Random Effects Logit Models through Stata's (STATACORP, 2015) "xtlogit" function, which is able to handle unbalanced panels. Firms with less than 7 years of data arise mostly because of the exclusion criteria adopted herein. Firm-years in which the shareholders' equity of the previous year became negative, with missing market value or extreme ROA were excluded from our sample.

Although not a variable in our models, the level of recognized impairment losses as a percentage of firm total assets in our sample has a mean 0.012 , with a standard deviation of 0.008 and a maximum of 0.117 . The fact that recognized impairment losses had a mean close to zero, considering that there are only 51 observations in which an impairment loss was recognized, is contrasted with the mean of unrecognized losses, of 0.1490, Suggesting that there are significant potential impairment losses being delayed or avoid by firms' management.

Table 5 - Summary Statistics

\begin{tabular}{|c|c|c|c|c|c|}
\hline & Mean & Min & Max & SD & Count \\
\hline Unrecognized losses $_{i, t}$ & 0.1490 & 0 & .7609 & 0.2557 & 1010 \\
\hline Debt to Equity ${ }_{i, t-1}$ & 0.6750 & 0.0037 & 1.4753 & 0.4614 & 1010 \\
\hline Short term debt ${ }_{i, t}$ & 0.3310 & 0 & 1 & 0.2221 & 1010 \\
\hline Financing Cash Flows ${ }_{i, t}$ & 0.0226 & -0.2667 & 0.8786 & 0.0977 & 1010 \\
\hline
\end{tabular}




\begin{tabular}{|c|c|c|c|c|c|}
\hline Fixed Assets $_{i, t}$ & 0.2547 & 0 & 0.9035 & 0.2334 & 1010 \\
\hline Intangible Assets $_{i, t}$ & 0.0910 & 0 & 0.8558 & 0.1697 & 1010 \\
\hline Goodwill $_{i, t}$ & 0.0095 & -0.0004 & 0.4729 & 0.0489 & 1010 \\
\hline Growth Opportunities $_{i, t}$ & 1.5392 & -179.1707 & 228.5177 & 14.3513 & 1010 \\
\hline Ownership $_{i, t}$ & 0.4819 & 0.0013 & 1 & 0.2585 & 1010 \\
\hline Payout $_{i, t}$ & 0.6748 & -11.4156 & 86.0448 & 3.9426 & 1010 \\
\hline Liquidity $_{i, t}$ & 0.2190 & 0 & 3.4934 & 0.4430 & 1010 \\
\hline $\mathrm{RET}_{i, t}$ & -0.0177 & -3.2642 & 3.4540 & 0.5005 & 1010 \\
\hline Volatility $_{i, t}$ & $4.77 \mathrm{e}-07$ & -0.00001 & 0.00011 & $5.54 \mathrm{e}-06$ & 1010 \\
\hline$\Delta C F_{i, t}$ & 0.0054 & -0.33350 & 0.2682199 & 0.0695 & 1010 \\
\hline$\triangle S A L E S_{i, t}$ & 0.0571 & -0.9946 & 1.1206 & 0.1509 & 1010 \\
\hline$\Delta E_{i, t}$ & -0.0022 & -0.5248 & 0.6033 & 0.0615 & 1010 \\
\hline$\Delta \mathrm{GDP}_{\mathrm{i}, \mathrm{t}}$ & 0.0126 & -0.0376 & 0.07528 & 0.0370 & 1010 \\
\hline$\triangle I N D R O A_{i, t}$ & -0.5234 & -18.2154 & 19.0645 & 2.6838 & 1010 \\
\hline $\log$ (assets) $)_{i, t}$ & 15.3100 & 11.6092 & 20.6180 & 1.4438 & 1010 \\
\hline Observations & 1010 & - & - & - & - \\
\hline
\end{tabular}

The aggregated level of impairment losses recognized in our sample, in the period from 2010 to 2016, totals R\$ 178 billion, a non-trivial amount for the size of the Brazilian stock market. However, Petrobras S.A and Vale S.A. are responsible for $97 \%$ of this amount, a percentage that reinforces the notion that the recognition of impairment losses in Brazil is a rare event, despite the fact that the percentage of unrecognized losses is significant. There are 307 firm-year observations with estimated unrecognized losses (30,39\% of our observations), with a conditional average unrecognized loss of $49 \%$ of the firm's assets. The dummy variable D_Bonds is evenly distributed, as 459 firm-year observations (45.45\%) have bonds in their liabilities, and 551 (54.55\%) firm-year observation do not.

In Table 6, we report the results of our set of Logit regressions based on Eq.1 with panel data treatment. Through models (1) to (4), we estimate Random Effects Logit Regressions considering specifications without controls (columns (1) and (3) and with controls (Columns (2) and (4), and also specifications without squared debt to equity ratios (columns (1) and (2) and with squared debt to equity ratios, in order to consider the potential non-linear effect between leverage and impairment recognition.

Table 6 - Tests of Hypothesis 1

\begin{tabular}{|c|c|c|c|c|}
\hline \multicolumn{5}{|c|}{ Panel A - Random Effects Logit Models } \\
\hline & (1) & (2) & (3) & (4) \\
\hline \multirow[t]{3}{*}{ Persistent Impairment Indicator } & 1.55385 & $2.22548^{*}$ & $1.40471^{+}$ & $2.82748^{+}$ \\
\hline & $(0.95393)$ & $(1.08850)$ & $(0.80350)$ & $(1.69445)$ \\
\hline & {$[4.72966]$} & {$\left[9.25796^{*}\right]$} & {$\left[4.07435^{+}\right]$} & {$\left[16.90276^{+}\right]$} \\
\hline \multirow[t]{3}{*}{ Debt to Equity } & 0.97125 & 0.78676 & 3.19469 & 0.24886 \\
\hline & $(0.60316)$ & $(1.18834)$ & (3.09842) & $(6.17484)$ \\
\hline & {$[2.64124]$} & [2.19627] & [24.40257] & {$[1.28256]$} \\
\hline \multirow[t]{3}{*}{ Debt to equity ${ }^{\wedge} 2$} & - & - & -1.41149 & 0.56943 \\
\hline & - & - & $(1.67584)$ & $(3.13588)$ \\
\hline & - & - & {$[0.24378]$} & {$[1.76726]$} \\
\hline \multirow[t]{3}{*}{ D_Bonds } & 0.58711 & 0.60864 & 0.69029 & 0.62253 \\
\hline & $(1.16191)$ & $(1.33851)$ & $(0.83286)$ & $(2.21670)$ \\
\hline & {$[1.79878]$} & [1.83793] & [1.99428] & [1.86363] \\
\hline \multirow{3}{*}{ Financing Cash Flows } & 1.62850 & 2.43038 & 1.23716 & 3.24840 \\
\hline & $(3.54733)$ & $(3.99001)$ & (3.34560) & $(5.28178)$ \\
\hline & {$[5.09620]$} & [11.36321] & [3.44583] & [25.74921] \\
\hline \multirow[t]{3}{*}{ Short term debt } & 0.55709 & -0.44900 & 0.66896 & -0.81734 \\
\hline & $(2.15237)$ & $(2.10041)$ & $(1.88621)$ & $(2.90776)$ \\
\hline & {$[1.74558]$} & {$[0.63827]$} & {$[1.95220]$} & {$[0.44161]$} \\
\hline Controls & No & Yes & No & Yes \\
\hline Wald chi2 & 35.359 & 401.506 & 44.127 & 478.205 \\
\hline p-value & 0.000 & 0.000 & 0.000 & 0.000 \\
\hline
\end{tabular}




\begin{tabular}{|c|c|c|c|c|}
\hline Observations & 1010 & 1010 & 1010 & 1010 \\
\hline \multicolumn{5}{|c|}{ Panel B - Average Marginal Effects } \\
\hline & (1) & (2) & (3) & $(4)$ \\
\hline \multirow{2}{*}{ Persistent Impairment Indicator } & $0.03279^{+}$ & $0.03788^{*}$ & $0.03433^{+}$ & $0.03835^{+}$ \\
\hline & $(0.01816)$ & $(0.01815)$ & $(0.01878)$ & $(0.02085)$ \\
\hline \multirow[t]{2}{*}{ Debt to Equity } & 0.02049 & 0.01339 & 0.02753 & 0.01426 \\
\hline & $(0.01575)$ & $(0.02089)$ & $(0.01831)$ & $(0.03450)$ \\
\hline \multirow[t]{2}{*}{ D_Bonds } & 0.01239 & 0.01036 & 0.01687 & 0.00844 \\
\hline & $(0.02192)$ & $(0.02219)$ & $(0.01972)$ & $(0.02687)$ \\
\hline \multirow[t]{2}{*}{ Short term debt } & 0.01175 & -0.00764 & 0.01635 & -0.01108 \\
\hline & $(0.04424)$ & $(0.03607)$ & $(0.04571)$ & $(0.04155)$ \\
\hline \multirow[t]{2}{*}{ Financing Cash Flows } & 0.03436 & 0.04137 & 0.03024 & 0.04406 \\
\hline & $(0.07458)$ & $(0.06723)$ & $(0.08193)$ & $(0.05994)$ \\
\hline
\end{tabular}

Standard errors in parentheses. Odds Ratios in square brackets. Constant term and control variables omitted for brevity. ${ }^{+} \mathrm{p}<0.1 * \mathrm{p}<0.05, * * \mathrm{p}<0.01, * * * \mathrm{p}<0.001$

Results in Panel A of Table 6 show statistical significance for Persistent Impairment Indicator as a predictor of recognized impairment losses only on columns (2), in which we do not account for the possibility of a non-linear effect between debt and impairment losses. Debt to equity is therefore only significant in our simplest model, without the possibility of a non-linear relationship between debt and the recognition of impairment losses. In addition, the squared debt to equity term is not significantly related to the recognition of impairment losses, providing evidence contrary to the hypothesis of a non-linear relation between impairment losses and debt. Variable Short-term debt, D_Bonds and Financing Cash Flows are not significant, reinforcing the suggestion that the actual recognition of impairment losses in Brazil is unaffected by debt concerns.

Since logistic regression accounts for a non-linear relationship between independent and dependent variable, the interpretation of its resulting coefficients in terms of economic significance is context depending. The odds ratio of the Persistent Impairment Indicator variable in column (2) if 9.25796, meaning that the odds of firms with this indicator to recognize an impairment loss are around nine times as large as the odds of their counterparts. In Panel B of Table 6, we show the Average Marginal Effects of our variables of interest on the likelihood of the firm recognizing an impairment, as suggested by Woolridge (2010). As shown in column (2) the probability of recognizing an impairment loss increases by approximately $3.8 \%$ when the firm is in a persistent BTM > 1 state, which is a rather small effect.

Regarding the effect of control variables (omitted for brevity), it is interesting to point out that growth opportunities are negatively related to the recognition of impairment losses in all of our specifications. This result is contrary to the prediction derived from Göx and Wagenhofer (2009) model, that firms with larger growth opportunities will adopt more conservative accounting practices. Since our proxy for growth opportunities is the investment cash flow (CAPEX) divided by fixed and intangible assets (Kallapur, \& Trombley, 1999; Adam, \& Goyal, 2008), this negative relation suggests that firms with larger current investment levels are less likely to recognize impairment losses, maintaining all of the other covariates constant.

The firm's payout level is positively related to the recognition of impairment losses, indicating that firms with a larger payout level would be more likely to recognize losses. This result could signal that managers desire to retain earnings. Since impairment losses are recognized as expenses in Profit \& Loss, they reduce the level of profits that are basis for the calculation of firm's minimum mandatory dividends. This result is in accordance with results from the survey presented in Decourt and Procianoy (2012).

We emphasize, however, that one should take our results, as reported in Table 6, with considerable caution. As we previously stressed, the recognition of impairment losses can be considered as a rare event in our sample of firm-year observations. Therefore, it is important to consider results reported in Table 6 in combination with results of our second model (Eq.(2)), in which we analyze determinants of the level of unrecognized impairment loss, a more frequent event 
observed in $30 \%$ of our sample. In our second model, we focus on debt related hypotheses $\mathrm{H} 2$ and H3. Our dependent variable is now the level of unrecognized losses. Given the frequency of firmyear observation with 0 unrecognized losses $(70 \%)$ and the fact that this variable is by construction bounded at 0 and 1, we estimate the parameters of Eq. 2 through Generalized Estimating Equation's approach, reporting our results in Table 7.

The negative coefficient of the Debt to equity variable (significant at the $1 \%$ level) in column (2) supports the argument that debt is negatively related to unrecognized losses, when this relation is specified as linear. This result is compatible with debt contracting as a source of demand for conservative accounting practices, providing evidence in favor of Watts (2003a) and Göx and Wagenhofer (2009). Firms with increased levels of debt are on average less prone to have unrecognized losses.

Results presented in Table 7, columns (3) and (4), show a statistically significant $(\mathrm{p}<0.01)$ and negative coefficient for the variable Debt to Equity squared, along with an inversion of the signal of debt to equity, which now has a positive effect on the level of unrecognized losses. The coefficients of these variables support a non-linear relationship between debt to equity and the level of unrecognized losses. This non-linear relationship, combined with the negative coefficient for Debt to Equity squared, results in an inverted u-shaped function, which shows that the level of unrecognized losses increases at decreasing rates as leverage increases. At a certain point, for larger levels of financial leverage, the level of unrecognized losses decreases at increasing rates as leverage increases.

Table 7

\begin{tabular}{|c|c|c|c|c|}
\hline \multicolumn{5}{|c|}{ Panel A - Generalized Estimating Equations - Logistic Link } \\
\hline & (1) & (2) & (3) & (4) \\
\hline \multirow[t]{3}{*}{ Debt to Equity } & $-0.34143^{+}$ & $-0.61254^{* *}$ & $2.32845^{* *}$ & $1.52322^{*}$ \\
\hline & $(0.19965)$ & $(0.18861)$ & $(0.74656)$ & $(0.70104)$ \\
\hline & {$\left[0.71075^{+}\right]$} & {$\left[0.54197^{* *}\right]$} & {$\left[10.26198^{* *}\right]$} & {$\left[4.58696^{*}\right]$} \\
\hline \multirow[t]{3}{*}{ Debt to equity $\wedge^{\wedge}$} & & & $-1.73048^{* * *}$ & $-1.36635^{* * *}$ \\
\hline & & & $(0.44072)$ & $(0.42135)$ \\
\hline & & & {$\left[0.17720^{* * * *}\right]$} & {$\left[0.25504^{* *}\right]$} \\
\hline \multirow[t]{3}{*}{ D_Bonds } & -0.23086 & -0.24484 & -0.25451 & -0.28329 \\
\hline & $(0.20999)$ & $(0.19956)$ & $(0.21339)$ & $(0.20041)$ \\
\hline & {$[0.79385]$} & {$[0.78283]$} & {$[0.77529]$} & {$[0.75330]$} \\
\hline \multirow[t]{3}{*}{ Short term debt } & $1.34217^{* * * *}$ & $0.94990^{*}$ & $1.59704^{* * * *}$ & $1.15850^{* * *}$ \\
\hline & $(0.35465)$ & $(0.38077)$ & $(0.37220)$ & $(0.40121)$ \\
\hline & {$\left[3.82736^{* * *}\right]$} & {$\left[2.58545^{*}\right]$} & {$\left[4.93841^{* * *}\right]$} & {$\left[3.18517^{* *}\right]$} \\
\hline \multirow[t]{3}{*}{ Financing Cash Flows } & $-4.88977^{* * *}$ & $-3.27951^{* * *}$ & $-4.98597^{* * *}$ & $-3.47861^{* * * *}$ \\
\hline & $(0.83947)$ & $(0.74396)$ & $(0.81335)$ & $(0.72857)$ \\
\hline & {$\left[0.00752^{* * *}\right]$} & {$\left[0.03765^{* * *}\right]$} & {$\left[0.00683^{* * *}\right]$} & {$\left[0.03085^{* * *}\right]$} \\
\hline Controls & No & Yes & No & Yes \\
\hline Wald chi2 & 97.352 & 442.929 & 113.928 & 446.854 \\
\hline $\mathrm{p}$-value & 0.000 & 0.000 & 0.000 & 0.000 \\
\hline Observations & 1010 & 1010 & 1010 & 1010 \\
\hline \multicolumn{5}{|c|}{ Panel B - Average Marginal Effects } \\
\hline & (1) & (2) & (3) & (4) \\
\hline \multirow[t]{2}{*}{ Debt to Equity } & $-0.03954^{+}$ & $-0.06589^{* *}$ & 0.01750 & -0.01715 \\
\hline & $(0.02315)$ & $(0.02106)$ & $(0.02348)$ & $(0.02334)$ \\
\hline \multirow[t]{2}{*}{ D_Bonds } & -0.02674 & -0.02634 & -0.02956 & -0.03067 \\
\hline & $(0.02412)$ & $(0.02137)$ & $(0.02466)$ & $(0.02167)$ \\
\hline \multirow[t]{2}{*}{ Short term debt } & $0.15545^{* * *}$ & $0.10218^{*}$ & $0.18552^{* * *}$ & $0.12543^{* *}$ \\
\hline & $(0.04024)$ & $(0.04143)$ & $(0.04140)$ & $(0.04358)$ \\
\hline \multirow[t]{2}{*}{ Financing Cash Flows } & $-0.56631^{* * *}$ & $-0.35277^{* * *}$ & $-0.57918^{* * *}$ & $-0.37663^{* * *}$ \\
\hline & $(0.09893)$ & $(0.07950)$ & $(0.09697)$ & $(0.07892)$ \\
\hline
\end{tabular}

Panel C - Marginal Effects of Debt at debt-to-equity quintiles' average

Debt to Equity

(1)

(2)

(3)

(4) 


\begin{tabular}{|c|c|c|c|c|}
\hline 1._at 0.1358 & $\begin{array}{l}-0.04429 \\
(0.02865)\end{array}$ & $\begin{array}{c}-\mathbf{0 . 0 7 8 6 8}{ }^{* * *} \\
(0.02889)\end{array}$ & $\begin{array}{c}0.19573 \\
(0.04892)\end{array}$ & $\begin{array}{c}0.12868^{*} \\
(0.05611)\end{array}$ \\
\hline \multirow{2}{*}{ 2._at 0.3680} & -0.04217 & $-0.07304^{* *}$ & $0.13759^{*}$ & 0.06422 \\
\hline & $(0.02617)$ & $(0.02540)$ & $(0.05617)$ & $(0.05031)$ \\
\hline \multirow[t]{2}{*}{ 3._at 0.5709} & $-0.04035^{+}$ & $-0.06817^{* *}$ & 0.04987 & -0.00472 \\
\hline & $(0.02405)$ & $(0.02239)$ & $(0.04489)$ & $(0.03591)$ \\
\hline \multirow[t]{2}{*}{ 4._at 0.8956} & $-0.03751^{+}$ & $-0.06060^{* * * *}$ & $-0.10509^{* * *}$ & $-0.10833^{* * * *}$ \\
\hline & $(0.02077)$ & (0.01777) & $(0.03254)$ & $(0.02687)$ \\
\hline \multirow[t]{2}{*}{ 5._at 1.4251} & $-0.03310 *$ & $-0.04912^{* * * *}$ & $-0.19371^{* * * *}$ & $-0.15919^{* * * *}$ \\
\hline & $(0.01583)$ & $(0.01115)$ & $(0.03289)$ & $(0.02754)$ \\
\hline
\end{tabular}

Standard errors in parentheses. Odds ratios in square brackets. Constant term and control variables omitted for brevity. ${ }^{+} \mathrm{p}<0.1 * \mathrm{p}<0.05, * * \mathrm{p}<0.01, * * * \mathrm{p}<0.001$

Average Marginal effects, reported in Table 7, Panel B, must be interpreted with caution, since they are calculated as first partial derivatives. Therefore, the estimate of the average marginal effect of the squared Debt to equity variable is non-applicable, since one cannot change the value of squared Debt to equity without changing the value of Debt to Equity itself. Because of this problem, we included in panel $\mathrm{C}$ of Table 7 estimates of the conditional marginal effects of debt to equity at the mean level of this variable in each of the five quintiles of its distribution. It becomes clear, particularly in columns (3) and (4), that at small values, debt to equity has a positive effect on the expected unrecognized losses, and as leverage increases, the effect turns increasingly negative, which is consistent with a non-linear relation between debt and unrecognized losses.

We also run an alternate specification of Eq2, substituting Debt to equity and its squared form with dummy variables that indicate the quintile in which a given firm is, in a given year, in terms of the distribution of debt to equity. Untabulated results show positive coefficients for the lower quintiles (although not statistically significant) and negative coefficients for the higher, most indebted quintile, with statistical significance at the $1 \%$ level. These results are in essence similar to the ones reported in Table 7.

The non-linear relation between debt and unrecognized losses is compatible with the notion that when debt becomes a more significant source of financing for the firms in our sample, the level of unrecognized losses decreases. This result may be derived from an increased reliance on balance sheet information by lenders when leverage levels are high. Theoretically, this could result on increased usage of collateral backing up debt external financing, which in turn might result in increased demand for accounting conditional conservatism. The use of collateral on financing arrangements is particularly important in the Brazilian market, where firms' access to debt financing is difficult (Zani, \& Procianoy, 2007).

The negative coefficient regarding Financing Cash Flows suggests that firms with higher amounts of debt issuance in year $t$ have lower levels of unrecognized losses, after controlling for the effects of Short-term debt and D_Bonds variables. Firms that have a higher level of cash flows from debt in year $t$ are less likely to have unrecognized impairment losses. This finding adds support for the debt contracting explanations for accounting conservatism. The positive and statistically significant (1\% level) coefficient of the Short-Term Debt variable, after controlling for other debt related variables such as financing cash flows and debt to equity, indicates that short term debt can substitute for accounting conservatism in mitigating agency costs. This result supports the relation suggested by Khurana and Wang (2015).

The effects of variable D_Bonds are not statistically significant, ceteris paribus, neither on the likelihood of recognizing an impairment loss (as estimated through Eq. 1) nor on the level of unrecognized losses (as estimated through Eq. 2). This result should be taken with caution, since there is evidence that a reasonable percentage of bond issued by Brazilian companies since 2010 are purchased by banks that coordinate the offering efforts (Carvalho, 2017). Since Banks, as private lenders, experience lower monitoring costs and have renegotiation advantages when compared with public debtholders (Florou, \& Kosi, 2015), their low reliance on balance sheet information could bias the coefficients of the D_Bonds variable. Future studies differentiating the effective holders of 
publicly held debt would be much welcome, although access to this information is not publicly available.

Finally, for additional robustness, we rerun Eq. 2 with a sample excluding Petrobras S.A and Vale S.A. Both companies have the most significant level of recognition of impairment losses in the sample, adding up to $97 \%$ of the aggregate booked impairment loss in the period. It is plausible that these two companies are inherently different from the other companies in our sample. Untabulated results with this exclusion are similar to those with the full sample in terms of the coefficients size, statistical significance and signal direction, meaning that our results are not particularly driven by these two companies.

\section{CONCLUSIONS}

The persistent observation of Brazilian firms with high BTM contrasted with the low frequency of impairment losses recognition is puzzling. As of December 31st, 2016, approximately $47 \%$ of the unique publicly traded firms in our sample had at least one observation with persistent $\mathrm{BTM}>1$, while only 21 unique firms effectively recognize losses. Although our study is performed on a large number of firm-year observations, our sample do suffer from a small number of impairment-recognizing firms. Considering this caveat, some of our results show a statistically significant relation between the persistent impairment indicator (high BTM) and the recognition of impairment losses, which suggests that some firms do consider market signals in the context of their impairment practices. However, these results are sensible to different model specification, and do not offer strong support for the role played by the BTM on the recognition of impairment losses.

Next, we turned our attention to the level of unrecognized losses, proxied by the percentage of firms' net assets that are not supported by the firms' market capitalization. We test and find significant evidence that debt contracting plays a complex role in explaining the level of unrecognized impairment losses. First, we find that short term debt is positively related to unrecognized losses, suggesting that short term debt in fact substitutes for accounting conservatism, as theorized by Khurana and Wang (2015). Second, we find an ambiguous relation between a firm's leverage and its level of unrecognized losses.

In our linear specification debt to equity is negatively related to the level of unrecognized losses, suggesting that more indebted the firm, the more conservative its accounting practices are. However, when we consider the possibility of a non-linear relation, we find evidence that there is an inverted u-shaped relation between debt and the level of unrecognized losses. For smaller levels of leverage, increases in debt are associated with an increase in the level of unrecognized losses, whereas for more indebted firms, increases in leverage reduce the level of unrecognized losses, suggesting that demand for accounting conservatism is significantly larger for financially constrained firms. That could be a particular feature of the Brazilian market, in which many firms are subject of severe financial constraints.

An important avenue for future research lies in exploring nuances of the relation between debt and impairment losses. Considering more details about the nature of the debt issued, including whether it has been issued within the company's home country or abroad, could contribute further to the extant literature on accounting conservatism and debt contracting. Separating the sample of firms in financially constrained and unconstrained firms can also constitute an interesting research contribution.

As the period of IFRS adoption in Brazil grows, we will be able to collect further data in order to increase the number of observations in which a firm has effectively recognized an impairment loss. We expect an increase in sample size to result in a significant increase of the explanatory power of econometric tests. In addition to that possibility, researchers will be able to test whether the puzzling lack of impairments can be attributed to a difficult learning curve of IFRS faced by Brazilian firms. The impairment related policies of these firms could also be compared with the corresponding 
policies of firms from other IFRS countries, in order to investigate the role played by different institutional settings in the phenomenon we observe in Brazil.

The widespread presence of the high BTM firms in the Brazilian stock market may indicate that firms are not conservative enough regarding their impairment-related practices. We believe that there is a fertile avenue for future research on the level of disclosure of impairment tests, its methodology, and its subjectivity. In this sense, firms with persistently high BTM should consider providing detailed and convincing disclosure of the reason their net assets are stated by amounts not supported by the market view of the firms' future cash flows. An approach with multiple case-studies, including the analysis of the disclosure of impairment tests of firms on variable BTM states should contribute further to the understanding of the complex phenomenon of impairment losses recognition.

\section{REFERENCES}

Adam, T., \& Goyal, V. K. (2008). The investment opportunity set and its proxy variables. Journal of Financial Research, 31(1), 41-63.

Amiraslani, H., Iatridis, G. E., \& Pope, P. F. (2013). Accounting for asset impairment: a test for IFRS compliance across Europe. Centre for Financial Analysis and Reporting Research (CeFARR).

André, P., Filip, A., \& Paugam, L. (2015). The effect of mandatory IFRS adoption on conditional conservatism in Europe. Journal of Business Finance \& Accounting, 42(3-4), 482-514.

Angrist, J. D., \& Pischke, J. S. (2008). Mostly harmless econometrics: An empiricist's companion. Princeton university press.

Armstrong, C. S., Taylor, D. J., \& Verrecchia, R. E. (2016). Asymmetric Reporting. Journal of Financial Reporting, 1(1), 33-35.

Ball, R., \& Brown, P. (1968). An empirical evaluation of accounting income numbers. Journal of Accounting Research, 159-178.

Ball, R., Kothari, S. P., \& Nikolaev, V. V. (2013). Econometrics of the Basu asymmetric timeliness coefficient and accounting conservatism. Journal of Accounting Research, 51(5), 1071-1097.

Ball, R., Robin, A., \& Sadka, G. (2008). Is financial reporting shaped by equity markets or by debt markets? An international study of timeliness and conservatism. Review of accounting studies, 13(2-3), 168205.

Banker, R. D., Basu, S., \& Byzalov, D. (2016). Implications of impairment decisions and assets' cash-flow horizons for conservatism research. The Accounting Review, 92(2), 41-67.

Banker, R., Basu, S., \& Byzalov, D. (2014). The role of multiple impairment indicators in conditional conservatism. Working Paper, 204-236.

Basu, S. (1997). The conservatism principle and the asymmetric timeliness of earnings1. Journal of Accounting and Economics, 24(1), 3-37.

Bini, M., \& Penman, S. (2013). Companies with Market Value below Book Value Are More Common in Europe than in the US: Evidence, Explanations, and Implications. Report, KPMG (24 April).

Bond, D., Govendir, B., \& Wells, P. (2016). An evaluation of asset impairments by Australian firms and whether they were impacted by AASB 136. Accounting \& Finance, 56(1), 259-288.

Carvalho, P. S. (2017). Perfil e Determinantes do Mercado de Debêntures no Brasil no Período 20042014 (Tese de Doutorado). Universidade Federal do Rio de Janeiro, Programa de Pós-Graduação em Economia, , Rio de Janeiro.

Chalmers, K., \& Godfrey, J. (2006). Intangible assets: diversity of practices and potential impacts from AIFRS adoption. Australian Accounting Review, 16(40), 60-71.

Choi, T. H. (2008). Asset Write-offs: An Empirical Investigation of Timeliness. Asia-Pacific Journal of Accounting \& Economics, 15(1), 11-27.

Danielson, M. G., \& Press, E. (2003). Accounting returns revisited: Evidence of their usefulness in estimating economic returns. Review of Accounting Studies, 8(4), 493-530.

Decourt, R. F., \& Procianoy, J. L. (2012). O Processo Decisório sobre a Distribuição de Lucros das Empresas Listadas na BM \& FBOVESPA: Survey com CFOs. Revista Brasileira de Finanças, 10(4), 461-498.

Detzen, D., Stork genannt Wersborg, T., \& Zülch, H. (2016). Impairment of Goodwill and Deferred Taxes Under IFRS. Australian Accounting Review, 26(3), 301-311. 
European Security Markets Authority. European enforcers review of impairment of goodwill and other intangible assets in the IFRS financial statements. Disponível em: <https://www.knf.gov.pl/knf/pl/komponenty/img/2013-02_report_on_goodwill_57461.pdf >.

Filip, A., Jeanjean, T., \& Paugam, L. (2015). Using real activities to avoid goodwill impairment losses: Evidence and effect on future performance. Journal of Business Finance \& Accounting, 42(3-4), 515-554.

Florou, A., \& Kosi, U. (2015). Does mandatory IFRS adoption facilitate debt financing? Review of Accounting Studies, 20(4), 1407-1456.

Gallani, S., Krishnan, R., \& Wooldridge, J. M. (2015). Applications of fractional response model to the study of bounded dependent variables in accounting research. Harvard Business School.

Gigler, F., Kanodia, C., Sapra, H., \& Venugopalan, R. (2009). Accounting conservatism and the efficiency of debt contracts. Journal of Accounting Research, 47(3), 767-797.

Glaum, M., Schmidt, P., Street, D. L., \& Vogel, S. (2013). Compliance with IFRS 3-and IAS 36-required disclosures across 17 European countries: company-and country-level determinants. Accounting and Business Research, 43(3), 163-204.

Goex, R. F., \& Wagenhofer, A. (2009). Optimal impairment rules. Journal of Accounting and Economics, 48(1), 2-16.

Guthrie, J., \& Pang, T. T. (2013). Disclosure of Goodwill Impairment under AASB 136 from 2005-2010. Australian Accounting Review, 23(3), 216-231.

Healy, P. M. (2016). Reflections on M\&A accounting from AOL's acquisition of Time Warner. Accounting and Business Research, 46(5), 528-541.

Jarva, H. (2014). Economic consequences of SFAS 142 goodwill write-offs. Accounting \& Finance, 54(1), 211-235.

Ji, K. (2013). Better late than never, the timing of goodwill impairment testing in Australia. Australian Accounting Review, 23(4), 369-379.

Kallapur, S., \& Trombley, M. A. (1999). The association between investment opportunity set proxies and realized growth. Journal of Business Finance \& Accounting, 26(3-4), 505-519.

Khurana, I. K., \& Wang, C. (2015). Debt maturity structure and accounting conservatism. Journal of Business Finance \& Accounting, 42(1-2), 167-203.

Knauer, T., \& Wöhrmann, A. (2016). Market reaction to goodwill impairments. European Accounting Review, 25(3), 421-449.

Kogan, L., \& Papanikolaou, D. (2014). Growth opportunities, technology shocks, and asset prices. The Journal of Finance, 69(2), 675-718.

Kothari, S. P. (2001). Capital markets research in accounting. Journal of Accounting and Economics, 31(1-3), 105-231.

Leuz, C., \& Wysocki, P. D. (2016). The economics of disclosure and financial reporting regulation: Evidence and suggestions for future research. Journal of Accounting Research, 54(2), 525-622.

Liang, K. Y., \& Zeger, S. L. (1986). Longitudinal data analysis using generalized linear models. Biometrika, 73(1), 13-22.

Lu, X. C., \& Trabelsi, S. (2013). Information asymmetry and accounting conservatism under IFRS adoption. In Anais, CAAA Annual Conference.

Mazzi, F., André, P., Dionysiou, D., \& Tsalavoutas, I. (2017). Compliance with goodwill-related mandatory disclosure requirements and the cost of equity capital. Accounting and Business Research, 47(3), 268-312.

Mazzioni, S., Politelo, L., Moreira, W. J., \& Klann, R. C. (2014). Fatores determinantes na evidenciação da redução ao valor recuperável de ativos (impairment test) em empresas listadas na Bm\&Fbovespa. Revista Base da UNISINOS, 11(4), 276-291.

Oler, M. (2015). Determinants of the length of time a firm's book-to-market ratio is greater than one. Review of Quantitative Finance and Accounting, 45(3), 509-539.

Papke, L. E., \& Wooldridge, J. M. (2008). Panel data methods for fractional response variables with an application to test pass rates. Journal of Econometrics, 145(1-2), 121-133.

Paugam, L., Astolfi, P., \& Ramond, O. (2015). Accounting for business combinations: Do purchase price allocations matter? Journal of Accounting and Public Policy, 34(4), 362-391.

Ramanna, K., \& Watts, R. L. (2012). Evidence on the use of unverifiable estimates in required goodwill impairment. Review of Accounting Studies, 17(4), 749-780. 
Riedl, E. J. (2004). An examination of long-lived asset impairments. The Accounting Review, 79(3), 823852.

Schiehll, E., Terra, P. R. S., \& Victor, F. G. (2013). Determinants of voluntary executive stock option disclosure in Brazil. Journal of Management \& Governance, 17(2), 331-361.

StataCorp, L. P. (2015). Stata statistical software (version release 14). College Station, TX: Author.

Szczesny, A., \& Valentincic, A. (2013). Asset write-offs in private firms-The case of German SMEs. Journal of Business Finance \& Accounting, 40(3-4), 285-317.

Szczesny, A., \& Valentincic, A. (2013). Asset write-offs in private firms-The case of German SMEs. Journal of Business Finance \& Accounting, 40(3-4), 285-317.

Watts, R. L. (2003a). Conservatism in accounting part I: Explanations and implications. Accounting Horizons, 17(3), 207-221.

Watts, R. L. (2003b). Conservatism in accounting part II: Evidence and research opportunities. Accounting Horizons, 17(4), 287-301.

Wooldridge, J. M. (2010). Econometric analysis of cross section and panel data. MIT press.

Wrubel, F., Marassi, R. B., \& Klann, R. C. (2015). Determinantes do reconhecimento de perdas por impairment em empresas brasileiras. Revista de Administração, Contabilidade e Economia da Fundace, 6(1).

Zani, J., \& Procianoy, J. L. (2007). Restrição Financeira e a Dependência de Colateral para o Endividamento das Firmas Brasileiras. In Anais, XXXI Encontro da ANPAD, Rio de Janeiro: ANPAD. 